\title{
High-dose deferoxamine treatment (intravenous) for thalassaemia patients with cardiac complications
}

F.R. Ghader, ${ }^{1}$ M. Kousarian ${ }^{1}$ and D. Farzin ${ }^{1}$

$$
\begin{aligned}
& \text { معابلة مرض الثلاسيميا المصحوب بمضاعفاث قلبية بجرعاث وريدية كبيرة من الديفيزوكسامين }
\end{aligned}
$$

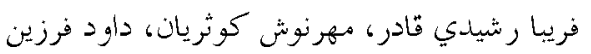

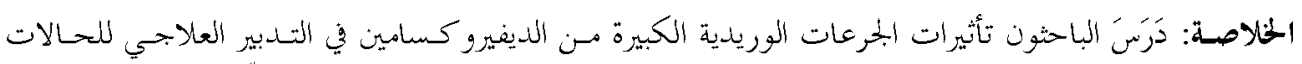

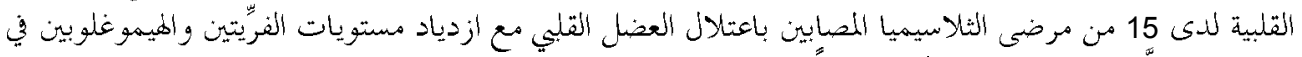

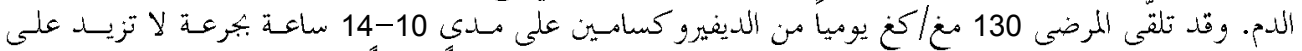

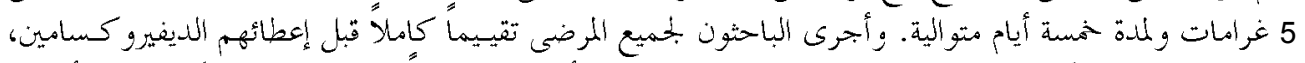

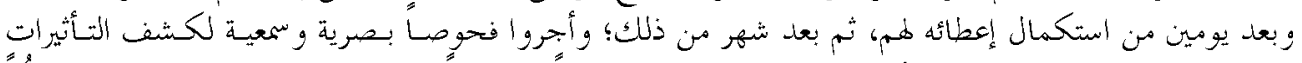

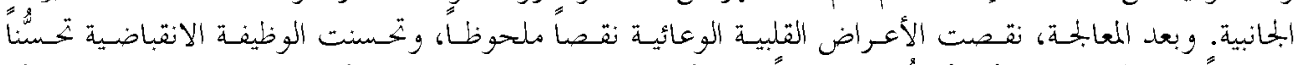

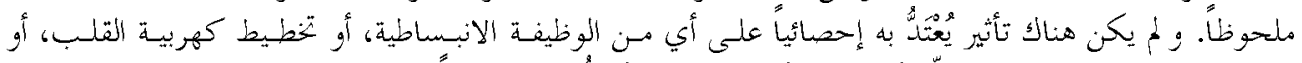

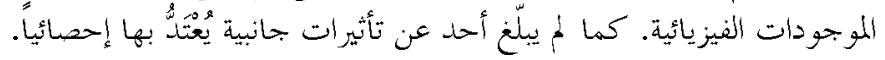

ABSTRACT As a means to manage cardiac conditions, we determined the effects of high-dose intravenous (IV) deferoxamine in 15 thalassaemia patients with cardiomyopathy and high ferritin and haemoglobin levels. The patients received IV deferoxamine, $130 \mathrm{mg} / \mathrm{kg}$ per day over 10-14 hours (maximum $5 \mathrm{~g}$ ) for 5 consecutive days. All patients underwent a full evaluation before receiving deferoxamine, and 2 days and 1 month after completing the treatment. Visual and auditory examinations were done to detect any side-effects. After treatment, cardiovascular symptoms decreased considerably and systolic function showed significant improvement, but there was no significant effect on diastolic function, electrocardiography and physical findings. There were no significant side-effects reported.

La déféroxamine (intraveineuse) à dose élevée dans le traitement de la thalassémie avec complications cardiaques

RÉSUMÉ Dans la perspective d'une prise en charge des cardiopathies, nous avons évalué les effets de la déféroxamine à dose élevée en perfusion intraveineuse (IV) chez 15 patients souffrant de thalassémie associée à une cardiomyopathie, une hyperferritinémie et une hyperhémoglobinémie. Pendant 5 jours consécutifs, les patients ont reçu de la déféroxamine à raison de $130 \mathrm{mg} / \mathrm{kg} / \mathrm{jour}$ en perfusion intraveineuse de 10 à 14 heures (dose journalière maximale : $5 \mathrm{~g}$ ). Tous les patients ont fait l'objet d'une évaluation complète avant l'instauration du traitement, puis 2 jours et 1 mois après l'arrêt de celui-ci. Des examens ophtalmologiques et otologiques ont été pratiqués afin de détecter d'éventuels effets secondaires. À l'issue du traitement, nous avons constaté une diminution considérable des symptômes cardio-vasculaires et une amélioration significative de la fonction systolique, toutefois il n'a été décelé aucun effet significatif sur la fonction diastolique ou les variables ECG ou physiques. II n'a été rapporté aucun effet secondaire significatif.

${ }^{1}$ Booali Hospital, Sari, Islamic Republic of Iran (Correspondence to F.R. Ghader: fashid83@yahoo.com). Received: 28/02/05; accepted: 30/10/05 


\section{Introduction}

Cardiac complications are among the most important causes of mortality and morbidity in patients with thalassaemia major [1]. These complications can be categorized into 3 different forms: acute pericarditis, congestive heart failure and arrhythmia due to haemosiderosis, and chronic anaemia [2].

The commonest treatment for thalassaemia patients, apart from bone marrow transplant which is done in only a few cases, is repeated blood transfusions [1]. Haemosiderosis is an unavoidable complication of prolonged blood transfusions [1,3-5]. Haemosiderosis, which plays a considerable role in early mortality, can be prevented or postponed by iron-chelating agents which allow the formation of more excretable iron complexes $[1,3]$. Iron chelation usually starts after 10-20 blood transfusions or once serum ferritin exceeds $1000 \mathrm{ng} / \mathrm{mL}$ [3]. Deferoxamine mesylate is a commonly used iron-chelating agent. Deferoxamine is a drug with high specificity, low toxicity and short half-life which can form a transportable deferoxamine-iron complex or ferrioxamine [1]. Several other regimens of iron-chelating agents have been developed, such as twice daily subcutaneous injection [6], oral agents including deferiprone (L1) [7-9] and ICL670 (Exjade) [4,10] and different intravenous (IV) regimens $[4,11-14]$.

Efforts have been made to establish a safe treatment of cardiac complications in thalassaemia patients. In one study on 17 patients with some degree of systolic dysfunction, continuous IV infusion of deferoxamine, $150 \mathrm{mg} / \mathrm{kg}$ per day over 10 hours for 7 days resulted in increased left ventricular ejection fraction (LVEF) [15]. In another study, $100 \mathrm{mg} / \mathrm{kg}$ per day IV deferoxamine given in the first 10 days of the month followed by subcutaneous administration of
$50 \mathrm{mg} / \mathrm{kg}$ in the next 20 days for a period of 8 months was evaluated. This regimen resulted in increased LVEF in 50\% of the patients [16]. In other studies similar regimens are recommended in selected patients. Thus appropriate regimens for managing cardiac conditions in thalassaemia major patients still need further investigation. Hence, we evaluated a high-dose deferoxamine infusion in thalassaemia patients with some degree of systolic function impairment.

\section{Methods}

This was a clinical trial comparing cardiac function in thalassaemia patients before and after treatment with high-dose deferoxamine. The study included 15 thalassaemia patients aged 15-25 years who had some degree of systolic dysfunction (LVEF < $55 \%$ ). Inclusion criteria were: taking cardiotonic drugs for at least a month, haemoglobin $>9 \mathrm{~g} / \mathrm{dL}$ and serum ferritin $>1200$ $\mathrm{ng} / \mathrm{mL}$.

After thorough explanation of the treatment and the study, written consent was obtained from patients or their parents. The study was carried out with the approval and cooperation of the thalassaemia ward of Booali Hospital.

The medical history of each patient was taken and they underwent a physical examination. Electrocardiography and echocardiography were performed on all the patients to determine pulse rate interval, QRS duration, arrhythmia and systolic and diastolic function. Their visual and auditory systems were also checked, and renal function tests and blood sugar were measured. Physical examination and echocardiography was done by a paediatric cardiologist using Littmann stethoscope and Med 750 Echocardiogram (Sonotron, Norway). Electrocardiography was done using a Davinsa 
electrocardiogram (Davinsa, Islamic Republic of Iran).

IV deferoxamine, $130 \mathrm{mg} / \mathrm{kg}$ per day over 10-14 hours (maximum $5 \mathrm{~g}$ ) was administered daily for 5 days to all patients. Blood pressure, pulse rate and respiratory rate were determined every 15 minute in the first 45 minutes of treatment, after which they were measured every 4 hours. Care was taken to detect and manage possible adverse effects of the drug including diplopia, tinnitus, skin rash and dizziness. The drug infusion was discontinued in patients developing all these adverse effects. The abovementioned procedures and examinations, including visual and auditory checks, were repeated at 2 days and 1 month after the completion of the infusion period. Occurrence of chest pain, palpitations, peripheral oedema, dyspnoea, heart sounds S3, S4 and systolic murmur were determined according to the patient's medical history and physical examination.

Kruskal-Wallis and ANOVA tests were used to compare qualitative and quantitative data before and after treatment.

\section{Results}

Demographic and clinical characteristics of the patients are given in Table 1. The mean age (standard deviation) of the 15 patients was 19.3 (SD 3.7) years; 10 males and 5 females. They all met the criteria for inclusion including starting transfusions at 20.0 (SD 14.2) months, starting deferoxamine at 5 (SD 0.48) years and taking cardiotonic drugs for at least 1 month (all patients were on digoxin, $93.3 \%$ on captopril and $80.0 \%$ on furosemide).

The majority of patients (13) had chest pain, 15 had palpitations and 14 had dyspnoea which after treatment decreased respectively to 1,2 and 1 patients at the

\begin{tabular}{|c|c|}
\hline \multicolumn{2}{|c|}{$\begin{array}{l}\text { Table } 1 \text { Demographic and clinical } \\
\text { characteristics of patients receiving high- } \\
\text { dose intravenous deferoxamine }\end{array}$} \\
\hline Characteristic & Mean (SD) \\
\hline Age of patients (years) & $19.1(3.7)$ \\
\hline Age at diagnosis (months) & $18.0(14.9)$ \\
\hline $\begin{array}{l}\text { Age at starting transfusion } \\
\text { (months) }\end{array}$ & $20.0(14.2)$ \\
\hline $\begin{array}{l}\text { Age at starting deferoxamine } \\
\text { (years) }\end{array}$ & $5.0(0.48)$ \\
\hline Age at splenectomy (years) & $9.0(5.2)$ \\
\hline $\begin{array}{l}\text { Haemoglobin level in the last } \\
\text { year }(\mathrm{g} / \mathrm{dL})\end{array}$ & $9.3(1.3)$ \\
\hline Deferoxamine dosage $(\mathrm{mg} / \mathrm{kg})$ & $38.9(72.0)$ \\
\hline $\begin{array}{l}\text { Deferoxamine taken (number } \\
\text { of nights per week) }\end{array}$ & $6(1)$ \\
\hline \multirow[t]{2}{*}{$\begin{array}{l}\text { Ferritin level before initiation of } \\
\text { deferoxamine }(\mathrm{ng} / \mathrm{mL})\end{array}$} & $1713.0(4.1)$ \\
\hline & $\begin{array}{c}\% \text { of patients } \\
\quad(n=15)\end{array}$ \\
\hline \multicolumn{2}{|l|}{ Thalassaemia complications } \\
\hline Diabetes mellitus & 13.3 \\
\hline Hypoparathyroidism & 60.0 \\
\hline Epilepsy & 6.7 \\
\hline Others & 33.3 \\
\hline \multicolumn{2}{|l|}{ Drugs taken } \\
\hline Digoxin & 100.0 \\
\hline Furosemide & 80.0 \\
\hline Captopril & 93.3 \\
\hline Rocaltrol & 53.3 \\
\hline Acetylsalicylic acid & 26.6 \\
\hline Amiodarone & 6.6 \\
\hline Calcium & 20.0 \\
\hline Folic acid & 13.3 \\
\hline Penicillin & 20.0 \\
\hline
\end{tabular}

$S D=$ standard deviation.

first evaluation (after 2 days of deferoxamine) and 3,4 and 3 patients at the second evaluation (a month after the discontinuation of deferoxamine) $(P<0.001)$ (Table 2 ). The number of patients suffering from peripheral oedema decreased from 15 to 


\begin{tabular}{|c|c|c|c|}
\hline Clinical feature & $\begin{array}{c}\text { Prior to } \\
\text { infusion } \\
\text { No. }\end{array}$ & $\begin{array}{c}2 \text { days after } \\
\text { the end of } \\
\text { infusion } \\
\text { No. }\end{array}$ & $\begin{array}{l}1 \text { month } \\
\text { after the } \\
\text { end of } \\
\text { infusion } \\
\text { No. }\end{array}$ \\
\hline Chest pain & 13 & 1 & 3 \\
\hline Palpitations & 15 & 2 & 4 \\
\hline Dyspnoea & 14 & 1 & 3 \\
\hline Peripheral oedema & 15 & 14 & 14 \\
\hline S3 or S4 & 1 & 1 & 1 \\
\hline Murmur $\geq 2 / 6$ & 15 & 15 & 15 \\
\hline Auditory complications & 0 & 1 & 0 \\
\hline Visual complications & 3 & 3 & 3 \\
\hline
\end{tabular}

14 on both evaluations, but no changes in heart murmur and other extra sounds were observed (Table 2). The mean LVEF increased from $49.1 \%(1.8 \%)$ to $58.8 \%$ (SD $2.9 \%$ ) in the first follow-up (not more than 2 days after ending the infusion period) and to $57.8 \%$ (SD $2.1 \%$ ) in the second followup $(1$ month later $)(P<0.0001)$. E-point-to septal separation (EPSS) of $9.6(0.8) \mathrm{mm}$ before the intervention decreased to 6.7 (SD 0.7$) \mathrm{mm}$ in the first follow-up and to 6.5 (SD 0.6$) \mathrm{mm}$ in the second follow-up $(P$ $<0.001)$ (Figure 1). No significant changes were found in diastolic function indices.

There were no patients with pulse rate interval $>0.2$ seconds, $\mathrm{QRS}>0.08$ seconds and significant arrhythmia before and after receiving IV deferoxamine (Figure 1).

No visual complications were noticed prior to the intervention but $2+$ retinal oedema occurred in 1 patient after completion of the infusion period. This condition was not detected in the visual evaluation 2 months later. There was a mild auditory decline in $20 \%$ of the patients prior to the intervention; this did not change after receiving defer- oxamine. As regards other side-effects, 2 patients developed mild urticaria and 2 others developed mild dizziness; all improved after decreasing the infusion velocity.

\section{Discussion}

Due to the high mortality and morbidity from cardiac complications in thalassaemia patients and to try to improve the treatment of these patients, we gave a high dose of IV deferoxamine (in addition to the continuation of the subcutaneous form) to 15 thalassaemia major patients to investigate its effects on cardiomyopathy. The results showed some degree of improvement in systolic but no change in diastolic functions.

In a study on 17 thalassaemia major patients with low systolic function and high ferritin level, an improvement in systolic function with no significant adverse effect was reported with high-dose deferoxamine [4]. In another study, 17 patients with cardiac complications such as cardiac ar- 

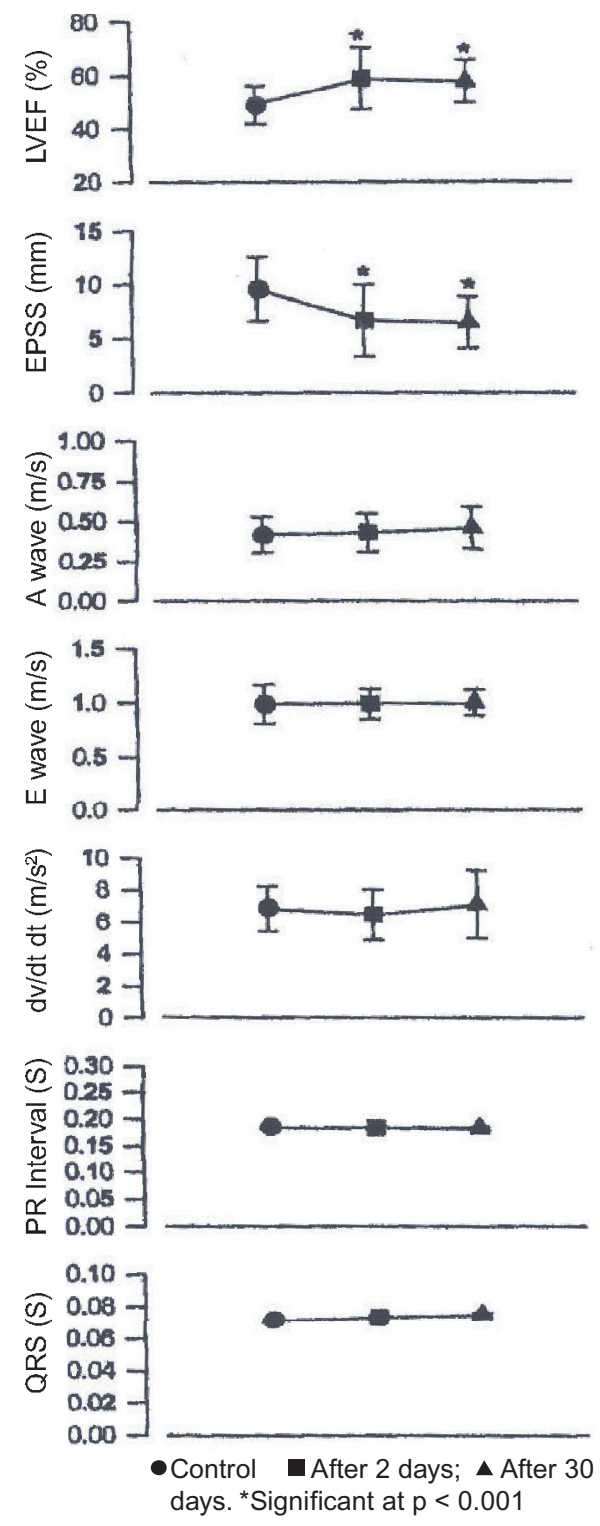

Figure 1 Echocardiography results of patients before and after treatment with highdose intravenous deferoxamine rhythmia and left ventricular dysfunction as well as intolerability of subcutaneous deferoxamine received IV deferoxamine via an in-dwelling IV line for about 16 years [12]. The result was improvement of arrhythmia in 6 out of 6 patients and LVEF in 9 out of 17 patients. These are in close agreement with the results of our study. Considering the considerable adverse effects of IV highdose deferoxamine, we used as low a dose of the medicine as possible which could lead to improved systolic function.

A significant relation has been reported between LVEF and CT2 (cardiac iron deposition confirmed by magnetic resonance imaging) in 113 thalassaemia patients [17], so it would seem that more aggressive ironchelating agents could produce greater improvements in LVEF. However, in another study, deferiprone L1 had more effect on myocardial iron removal than deferoxamine [18]. Furthermore, combination therapy of these 2 medicines had a synergistic effect in 2 patients confirmed by magnetic resonance imaging [18].

Several other routes for administering iron-chelating agents have been developed, such as twice daily subcutaneous injection [6], oral agents including deferiprone (L1) [7-9] and ICL670 (Exjade) [4,10] and different IV regimens [4,11-14]. We chose this route to try and establish the optimal regimen in high-risk patients so we selected those who may best benefit from IV chelation. Our study had a short-term follow-up period so this type of deferoxamine administration may only have a temporary effect. Prolonged IV administration and follow-up are needed to better evaluate this regimen of treatment.

Regarding side-effects of high-dose deferoxamine, some mild skin eruption and dizziness were observed which were 
managed by lowering the infusion rates. Visual complications were observed in only 1 of our 15 patients. In our hospital there has been an case of a patient who self-administered an unusually high dose of deferoxamine $(120 \mathrm{mg} / \mathrm{kg}$ for 3 months $)$ which resulted in lenticular lesion (snow dot spot); this improved after returning to the usual dose.

Adverse effects of deferoxamine on visual (night blindness, retinopathy), auditory (signal-to-noise hearing loss, tinnitus), neurological (neuropathy, encephalopathy) and renal systems as well as growth retardation (with high dose deferoxamine in patients under 3 years) and increased susceptibility to infection (Yersinia infection, mucormycosis) are well documented. With higher dose IV deferoxamine, other anaphylactic reactions have been reported, such as hypotension, aphasia, acute respiratory distress syndrome and diarrhoea [19-23]. None of these reactions was observed in our patients. It has been suggested that measurement of plasma metabolite or the relative proportion of deferoxamine and ferrioxamine may help identify patients at risk of excessive dosing [24,25].
Our findings suggest that high-dose IV deferoxamine could provide some degree of improvement in the treatment of systolic function of cardiomyopathy in thalassaemia patients. A long-standing concern in high-dose IV deferoxamine is its numerous adverse effects. Our study and similar ones demonstrate that these adverse effects are manageable with meticulous care and it may be worthwhile to use the high-dose IV route in treatment of cardiomyopathy in patients with high ferritin levels.

\section{Acknowledgements}

We thank the Research Center of Mazandaran Medical University for expert advice and financial support. We also thank the staff and patients at the Thalassaemia Department of the Booali Hospital of Sari for their cooperation and participation.

The study was financed by the Paediatric Department of Booali University Hospital, Mazandaran University of Medical Sciences, Islamic Republic of Iran.

\section{References}

1. Miller DR, Baehner RL, Miller LP, eds. Blood disease in infancy \& childhood. St Louis, Mosby, 1995:443-82.

2. Allen HD et al. Moss and Adam's heart disease in infants, children and adolescents, 6th ed. Philadelphia, Lippincott Williams \& Wilkins, 2000:1263.

3. Behrman RE, Kliegman RM, Jenson HB. Nelson textbook of pediatrics, 17th ed. Philadelphia, WB Saunders, 2000:14845.

4. Galanello R. Iron chelation: new therapies. Seminars in hematology, 2001, 38(1 suppl. 1):73-6.
5. Riva Aet al. Type 3 hemochromatosis. European journal of hematology, 2004, 72:370-4.

6. Borgna-Pignatti $\mathrm{C}$, Cohen A. Evaluation of a new method of administration of the iron chelating agent. Journal of pediatrics, 1997, 130(1):86-8.

7. Olivieri NF, Brittenham GM. Iron chelating therapy and the treatment of thalassemia. Blood, 1997, 89(3):739-61.

8. Loebstein $\mathrm{R}$ et al. Immune function in patients with beta thalassaemia receiving the orally active iron-chelating agent de- 
feriprone. British journal of haematology, 1997, 98(3):597-600.

9. Mazza $P$ et al. Oral iron chelating therapy. Haematologica, 1998, 83(6):496-501.

10. Cappellini MD. Iron-chelating therapy with the new oral agent ICL670 (Exjade). Best practice \& research. Clinical haematology, 2005, 18(2):289-98.

11. DeSwarte-Wallace J, Groncy PK, Finklestein JZ. Iron chelation with deferoxamine: comparing the results of a critical pathway to a national survey. Journal of pediatric hematology/oncology, 1999, 21(2):136-41.

12. Davis BA, Porter JB. Long term outcome of continuous 24-hr DFO infusion. Blood, 2000, 95(4):1229-36.

13. Boturao-Neto E, Marcopito LF, Zago MA. Urinary iron excretion induced by intravenous infusion of deferoxamine in beta-thalassemia homozygous patients. Brazilian journal of medical and biological research, 2002, 35(11):1319-28.

14. Miskin $\mathrm{H}$ et al. Reversal of cardiac complications in thalassemia major by long-term intermittent daily intensive iron chelation. European journal of hematology, 2003, 70(6):398-403.

15. Ehsani MA, Hedayati AA, Seighali AF. Evaluation of high dose intravenous Desferal therapy in thalassemia major patients with heart failure. Paper presented at the 9th International Conference on Thalassemia and Hemoglobinopathies, O56, 15-19 October, 2003, Palermo, Italy (http://www.soste.org/archivio/docs/TIF. pdf, accessed 12 February 2007).

16. Di Gregorio F et al. Chelazione intensiva per via venosa in pazienti talassemici ipersiderotici [Intensive intravenous chelation in thalassemic patients with iron overload]. Minerva pediatrica, 1988, 50(3):81-5.
17. Hatziliami A et al. Heart MRI findings in transfusion-dependent thalassemia major patients. Paper presented at the 9th International Conference on Thalassemia and Hemoglobinopathies, O56, 15-19 October, 2003, Palermo, Italy.

18. Peng CT, Wu KH, Tsai C.H. Combined therapy with deferiprone and desferrioxamine successfully regress severe heart failure in patients with beta thalassemia major. Paper presented at the 9th International Conference on Thalassemia and Hemoglobinopathies, O56, 15-19 October, 2003, Palermo, Italy (http://www. soste.org/archivio/docs/TIF.pdf, accessed 12 February 2007).

19. Haimovici $R$ et al. The expanded clinical spectrum of deferoxamine retinopathy. Ophthalmology, 2002, 109(1):164-71.

20. Kushner JP, Porter JP, Olivieri NF. Secondary iron overload. Hematology, 2001:47-61.

21. Lai TYY. Rapid development of severe toxic retinopathy associated with continuous intravenous deferoxamine infusion. British journal of ophthalmology, 2006, 90:243-4

22. Dickerhoff R. Acute aphasia and loss of vision with desferrioxamine overdose. American journal of hematology and oncology, 1987, 9(3):287-8.

23. Ocular toxicity of high-dose intravenous desferrioxamine. Lancet, 1983, 2(8343):181-4.

24. Porter JB. Deferoxamine pharmacokinetics. Seminars in hematology, 2001, 38(1 suppl. 1):63-8.

25. Kruck TP et al. High performance liquid chromatographic analysis of desferrioxamine. Journal of chromatography, 1988, 433:207-16. 